\title{
Corporate collusion in the petroleum and defense industries: a theoretical approach
}

\author{
Rammy Haija \\ Department of Sociology, Pacific University, Forest Grove, Oregon, OR, USA \\ Email address: \\ rhaija@pacificu.edu
}

To cite this article:

Rammy Haija. Corporate Collusion in the Petroleum and Defense Industries: A Theoretical Approach. Social Sciences. Vol. 2, No. 3, 2013, pp. 112-127. doi: 10.11648/j.ss.20130203.13

\begin{abstract}
While interlocking directorates have been misused in Corporate America for decades, traditionally this misuse is in violation of the various antitrust act legislations. Since corporate collusion generally occurs between companies in common industries, and most often involves price fixing or manipulating supply of a product to yield greater pricing and profits, these antitrust violations are often a foregone conclusion. This case study analyzes a type of corporate collusion through interlocking directorates that is far more ominous, exploring the power of interlocking directorates and demonstrating how they may have been misused to manipulate foreign policy and military strategies, and in this case study, how the petroleum and defense industries may have benefitted from these actions.
\end{abstract}

Keywords: Interlocking Directorates, Corporate Collusion, Antitrust, Petroleum Industry, Defense Industry

\section{Power of Interlocking Directorates}

Research on interlocking directorates began to emerge at the turn of the $20^{\text {th }}$ century (Domhoff, 2005a). In 1913 U.S. Supreme Court Justice Louis Brandeis warned that interlocking directorates contained elements of danger and that competition could be threatened through these interlocks (Pennings, 1980). Despite Justice Brandeis' warning and corresponding emerging research, the $20^{\text {th }}$ century bore witness to the intense infusion of this threat throughout the corporate directorship structure. While there was increasing discussion by pluralists during the midcentury that elites in advanced capitalist societies were becoming more "atomized," elite theorists in the 1950s and 1960 s argued against competing notions that elites in advanced capitalist societies were becoming less integrated, and that despite disagreements, they remain highly intertwined (Mizruchi \& Koenig, 1986). ${ }^{1}$

These interlocks may well have been strategically executed toward creating co-dependence between the petroleum industry and military defense contractors. Furthermore, some of these firms and directors

\footnotetext{
${ }^{1}$ Mizurchi \& Koenig refer to work pluralist work of Riesman, 1953; Dahl, 1961; and Rose, 1961; and to the elite theory work of Hunter 1953, 1959; Mills, 1956; and Domhoff, 1967, 1970.
}

have exhibited a sense of disregard for the legal guidelines for corporations as set by the state.

\section{Purpose of Interlocks}

R. Jack Richardson (1987) differentiates between two types of directorship interlocks: interorganizational interlocks, which perform an interorganizational function and are considered mechanisms of co-optation and control; and integrative interlocks, which are seen as "fulfilling integrative functions that transcend narrow corporate interests" (p. 367), and have the purpose of satisfying the need for "class consolidation or elite integration." (Richardson, 1987, p. 367). Richardson (1987) finds that co-optive, or interorganization interlocks are far less frequent than integrative interlocks. This suggests that when interlocks are not in place for the purpose of corporate profitability, such as a financial executive seated on the board of an indebted non-financial company, they exist to fulfill an integrative function which "transcends narrow corporate interests" (Richardson, 1987, p. 384). However, Richardson may have overlooked industries that are not interdependent in theory, but function as such for all practical measures, such as the petroleum and defense industries.

An exploratory study by Johannes M. Pennings (1980) 
concludes that interlocks provide strategic advantages for corporations by granting greater access to capital and environmental control. It is argued that these interlocks work to reduce economic and environmental uncertainty (Pennings, 1980; Pfeffer \& Salancik, 1978). In analyzing the Pennings study, Richard H. Hall (2002) explains there are two basic ways to view this strategic edge: (1) a means to achieve a competitive advantage, or (2) as conspiratorial. Hall (2002) suggests that both views contain undeniable elements of truth.

In contemporary context, interlocking directorates are concerning on multiple fronts. Firstly, they embolden a ruling class by consolidating power of the major Fortune 500 companies into fewer hands. Secondly, there is an aura of conspiracy when a tight web of connections exists between differing industries that capitalize on the same policy agendas. This article seeks to address the clouded relationship between U.S. petroleum corporations and U.S. defense contractors through an inter-industrial interlocks matrix and an analysis of the circumstantial evidence that may gave indications of the implications of this relationship.

The primary theoretical reasoning for why these interlocking directorates occur, and why these firms are so highly intertwined are that interlocks reduce industry uncertainty as a "profit-maximizing strategy" (Schoorman et al, 1981). Previous studies have argued that interlocking directorates are partially a result of causal relationships, such as regional proximity (Burris, 2005) or networking factors (Bearden \& Mintz, 1985).

\section{Statement of Problem}

Few attempts have been made toward examining the directorate link between two of the most globally lucrative industries, the petroleum and defense industries. ${ }^{2}$ This research examines (1) the extent to which a fraction of the capitalist class has used interlocking corporate directorates to conjoin the global petroleum and global defense industries in the context of capital-to-capital and capital(s)to-state relations (Ross and Trachte, 1990), and (2) these interlocks' larger political-economic implications.

The implications of this analysis in present-day context should be obvious: a petroleum-defense network could significantly influence American foreign policy in a manner that may be best suited for their interests instead of those of the country. While public support for the U.S.-led invasion of Iraq may have been due to the fear that the

\footnotetext{
2 Of the 2000 companies featured on the 2005 version of the "Forbes 2000 " listing of largest corporations in the world, 90 companies were classified under "Oil and Gas Operations" - the most of any industry, while 19 were classified under "Aerospace and defense," with several other defense related contractors such as United Technologies and General Electric classified under "Conglomerates" because of the variety of their corporate ventures.
}

country possessed weapons of mass destruction, another explanation is certainly plausible. Increased military spending is certainly favored by the defense industry, and the allocation of billions in defense monies for the U.S.-led invasion of Iraq appears to have been largely supported by the petroleum industry who viewed an American-controlled Iraq as an opportune means at tapping into the vast oil fields of this Persian Gulf nation (Perkins, 2004). Despite the seeming simplicity of motivation for such a possible collusion, little research has been done toward assessing mechanisms through which this strategic power alliance might operate.

The G.W. Bush administration argued that the "stabilization" of petroleum-rich regions is of national interest, and therefore is a vital part of the national agenda, and in some instances this "stabilization" process involves the U.S. military (Weinstein, 2004). Thus, it is little surprise that petroleum companies, along with military contractors, have found this "stabilization" process to be a very lucrative venture. According to a joint report by the Institute for Policy Studies and United for a Fair Economy (2006), the average compensation for CEOs in the petroleum and defense industry in the Post 9/11 era has increased dramatically in comparison with other industries and the S\&P 500 average:Since the 'War on Terror' began, the CEOs of the top 34 defense contractors enjoyed average pay levels that are double the amounts they received during the four years leading up to 9-11.defense CEO pay was 108 percent higher on average in 2005 compared to 2001.[and] since 9-11, the 34 defense CEOs in our sample have pocketed a combined total of $\$ 984$ million (IPS and UFE, 2006, p. 1).

Also benefiting greatly from the "War on Terror" are private security contractors (PSCs), such as $\mathrm{Xe}$ and DynCorp, which are mercenary groups hired by not only the U.S. government to conduct specific operations, but also utilized by petroleum corporations to provide protection and support in the security of the petroleum resources (Dao, 2004). Occidental Petroleum is one company featured in this study that has used PSCs to protect oil fields against dispossessed indigenous peoples attempting to reclaim their land. A Business \& Human Rights Resource Centre (2007) report on private security and human rights excerpts a Los Angeles Times article describing the bombing of a Colombian village in which a PSC helped facilitate:[In] the Bombing of Santo Domingo....11 adults and seven children died on Dec. 13, 1998..But according to Colombian military court records, the U.S. government helped initiate military operations around Santo Domingo that day, and two private American companies helped plan and support them... Occidental Petroleum, which runs an oil complex 30 miles north of Santo Domingo, provided crucial assistance to the operation. It supplied, directly or through contractors, troop transportation, planning facilities and fuel to Colombian military aircraft, including the helicopter crew accused of 
dropping the bomb. AirScan Inc., a private U.S. company owned by former Air Force commandos, helped plan and provided surveillance for the attack around Santo Domingo using a high-tech monitoring plan....Company employees even suggested targets to the Colombian helicopter crew that dropped the bomb....AirScan officials deny involvement in the incident, saying their plane was used only to survey Occidental's oil pipeline, and the company is not accused of any illegal activity (Los Angeles Times, 2002).

The use of PSCs in Iraq has been substantial. According a 2008 report published by the Congressional Research Service, "some 20 different PSCs, employing 10,000 people, are working directly for the U.S. government, primarily for DOD and the Department of State" (p. 8). The use of these PSCs has become a controversial issue, as Xe (known as Blackwater Worldwide prior to February $2009)^{3}$ has been accused of acting with reckless regard for civilian life in Iraq. One specific example is a September 2007 incident in which Xe guards opened fire on a civilian crowd in Iraq killing 17 people, which a probe later found was unprovoked (BBC News, 2007). The Xe guards involved in this incident could not be tried in Iraqi courts, however, because the U.S. government had negotiated immunity for U.S. civilian contractors from any Iraqi prosecution for crimes committed in Iraq. While this was reversed in December of 2008, the contractors involved in the incident still could not be prosecuted in Iraq because this incident occurred before the new agreement $(\mathrm{CNN}$, 2009). As a result of the September 2007 incident, the interior ministry of Iraq elected in January of 2009, not to grant an operating license to $\mathrm{Xe}$, ensuring that $\mathrm{Xe}$ can no longer operate inside of Iraq.

There are other examples of firms in the petroleum or defense industries showing a lack of humanitarian regard or sovereignty; among them, Chevron's continual political interference in Nigeria (Goodman \& Scahill, 1998), or the ExxonMobil backed plan to overthrow the ruling government in Equatorial Guinea using a mercenary force similar to Xe and Dyncorp (Pelton, 2006) can be used to highlight the less than ethical means petroleum companies will go to procure resources. More recently it has become critical to examine the tactics petroleum firms use for acquiring these petroleum opportunities because of the "blowback" that the U.S. experienced on September $11^{\text {th }}$ 2001 (Johnson, 2006). A Washington Post article reported the sharp drop of the U.S. in world opinion polls which is attributed to a few factors, namely the Iraq War and U.S. hypocrisy regarding U.N. participation and with other international bodies (Sullivan, 2007).

\footnotetext{
Blackwater Worldwide was renamed, Xe, in February of 2009. According to the Guardian (2009), "Blackwater Worldwide is abandoning its tarnished brand name as it tries to shake a reputation battered by oft-criticised work in Iraq...the decision comes as part of an ongoing rebranding effort that grew more urgent following a September 2007 shooting in Iraq that left at least a dozen civilians dead."
}

The Executive Excess report (IPS \& UFI, 2006) documents the dramatic increase in the salaries of defense industry CEOs and how the two primary industries benefiting from the Iraq war are defense and petroleum. A growing concern among these types of corporate watchdog groups is over interlocking directorates becoming more prevalent in industries that capitalize off military-driven foreign policy (IPS \& UFI, 2006). This is a continuation of the concerns associated with the "military-industrial complex" warned against by President Dwight D. Eisenhower in his farewell address in 1961. This militaryindustrial complex "refers to interorganizational patterns linking military with industry into a powerful set of organizations that can dominate other spheres of life" (Hall, 2002, p. 217). Harris argues that during George W. Bush's (G.W. Bush) term in office, this military-industrial complex became increasingly dominant (Harris, 2005), and when partnered with an industry (in this analysis, the petroleum industry), that requires the use of military or state participation to procure greater access to this vital resource. This presents the necessity of studying whether a capitalto-capital relationship toward mutual benefit between the petroleum and military-defense industries has been established.

\section{Theoretical Significance ${ }^{4}$}

Much of the theoretical significance of interlocking directorate research is what it indicates about capitalist class structure in the U.S. To the extent that a class exists, it is at least a class "in itself" (a class an sich, or an "objective" class) in that it is a collectivity distinguishable by its relation to means of production and labor performance. But a class is far more effective in pursuing its interests when its members identify with each other and intentionally act in a coordinated way - a class "for itself" (a class für sich, or a "subjective" class whose members are conscious of their common interests). Working classes often lack such a strong sense of class consciousness, rendering them weak in any effort to pursue their class interests, but capitalist classes tend to possess a substantial measure of class consciousness, facilitating their dominance [Wright, 1996; Marx 2008 (1847)].

Directors of large corporations are a disproportionately capitalist lot, and they are directly engaged in the organized pursuit of profit for corporations, and thus in the pursuit of profit for those who own enough corporate stock and other forms of capital to make a comfortable living as a capitalist. But a capitalist sitting on boards of two or more corporations simultaneously helps to coordinate not just the capitalists with a particular interest in a particular capitalist firm, but the larger capitalist class in a society.

\footnotetext{
${ }_{4 \text { Some of this discussion is adapted from a paper presented at the Southern }}$ Sociological Society Annual Meeting in Richmond, VA in April of 2008, (Haija et. al, 2008).
} 
This coordination occurs simultaneously in corporations and state institutions. Domhoff (2005a, 2005b) explains that the problem with the corporate community becomes economic control, which translates to policy influence. As Domhoff (2005a) explains, "[c]entrality is a concept with two components, a large number of interlocks, plus the degree to which those interlocks are with other companies with a large number of interlocks." According to Richard H. Hall (2002), "[i]t is imperative to note that interlocks are purposive" (p. 240). If collusion is occurring between the petroleum and defense industry we would expect to find indicators that would substantiate this, such as greater interlocks among top firms within these industries, cooperation between these two industries in attempting to influence policymaking, and mutually benefiting from specific governmental policies or actions. These potential indicators of collusion will be studied thoroughly and measured both quantitatively and qualitatively to make a sound assessment as to whether these interlocks provide the foundation for a larger collusion at work between the U.S. petroleum and defense industries.

As stated previously, organizational theory posits that there is a necessity for interlocking directorates because of environmental uncertainty. As Richardson (1987) suggests, "corporation[s] only attempt to co-opt organizations that control scarce essential resources, and a firm will not pursue this strategy if it can achieve its aims by competition or bargaining" (p. 369). This article seeks to reveal the extent that the U.S. defense and petroleum industries interlock and these interlocks larger politicaleconomic implications. Thus, interlocks are not necessarily exercised as a means of controlling capital, but in this case, they could be a means of controlling policy as there are only a few reasons why defense and petroleum would see the need to create such strong interlocks between their industries.

There is one type of interlock examined in this study, a "direct interlock" (Hall and Tolbert, 2005). Specifically, the direct interlocks examined in this study are between petroleum and defense. However, another key component of this study will be to examine which board members from defense and petroleum firms held former government positions. Direct interlocking directorates occur when a person sits on the board of directors of separate organizations. This person creates a direct interlock between the organizations for which that person sits on. A government interlock is characterized by a sitting board member previously holding a legislative, bureaucratic position, or military leadership post. The interlock is marked by a linkage between the corporate and policy realms because of their seemingly greater ability to provide access to policymakers. Indirect interlocks are not addressed in this study. An interlocking directorate is when "two organizations are linked by a path through one or more third organizations" (Pennings, 1980, p. 37). According to Pennings (1980) there is not sufficient evidence that indirect interlocks have the strength or relevance to work as a co-opting agent, and therefore this was the justification for omitting them from this study. Organizational researchers such as Domhoff have used indirect interlocks within their research, such as in his series, Who Rules America? (Domhoff, 2002). However, Domhoff's purpose of incorporating indirect interlocks in his study was to show the far reachability of indirect interlocks, in instances where direct interlocks have only a limited reaching capacity. The purpose of this study is not to show the reachability of interlocks within any industry, but rather to demonstrate the significance of the strong corporate connection between the petroleum and defense industries and the possible implications on U.S. foreign policy when these two industries have their corporate interests overlap.

\section{Interorganizational Relationships}

The work of Talcott Parsons lends heavy credence to why interlocks exist. Parsons (1960) devised a model that showed how societies and social organizations must carry out specific functions to ensure their survival. This model, known largely by its acronym of the AGIL scheme, focuses on four functions necessary for survival: Adaptation, Goal attainment, Integration, and Latency. Of those four functions, adaptation is most important to this study. Adaptation refers specifically to how organizations adjust to meet their needs and necessities for their success and survival, and more specifically, it directs an organization to the approaches and strategies it must take to gain the resources necessary to best provide its service, product, or objective. An interlocking directorate exists precisely because of the necessary survival function of adaptation. Most organizational theorists agree that there will always be a degree of cohesion between organizations to allow for the control of environmental uncertainties (Aldrich, 1979; Pfeffer and Salancik, 1978; Pennings, 1980; Zald, 1970). Therefore, since adaptation is such a crucial form of an organization's survival, and interlocking directorates are considered a necessity because of environmental uncertainties, organizational performance could be gauged by the level of interconnectedness a particular organization has with other organizations that alleviate some of their environmental uncertainties. ${ }^{5}$

This study can most simply be explained as an examination of the implications and outcomes of one particular "interorganizational relationship." Before I go further into this relationship, it is first necessary to define inter-organizational relationships (IORs). There is a general agreement among organizational theorists that IORs have

\footnotetext{
${ }^{5}$ The discussion layout in the opening paragraph and the interorganizational relationships section of this literature are derived from the works of Hall, 2002; Hall and Tolbert, 2005; and Jaffee, 2001
} 
three basic forms which are drawn from the work on interorganizational role set analysis by Merton (1957), Evan (1966) and Caplow (1964). Hall and Tolbert (2005) differentiated between three forms of IORs: (a) dyadic interorganizational relationships; (b) interorganizational sets; and (c) interorganizational network. A dyadic relationship is the most frequently discussed form of an interorganizational relationship, and it is simply a relationship between two entities. According to Caplow (1964) and Evan (1966) dyadic relationships present researchers with the simplicity of being able to follow the effect, if any, on one entity when its dyadic partner forms a relationship with it. ${ }^{6}$ This is because once that relationship is formed, it allows for some assessment (when controlling for other variables) of the positive or adverse changes that have occurred in both of the firms that form the interlock. Further examination can allow us to assess whether those changes or effects were a result of that particular dyadic relationship, or simply a spurious relationship. Specifically these affects can have an impact on profitability, accessibility to other firms, and can bolster lobbying influence and access to policymakers (Fenno, 1978).

An interorganizational set is comprised of "a group of organizations formed in a temporary alliance for a limited purpose" (Aldrich, 1979, p. 281), where the central point is the focal agency and each specific dyadic relationship it has with other organizations. Generally the focal agency is one in which many different actors or organizations must rely on for their success and or survival. In a broad example, many organizations find it in their interests to interlock with a banking institution should they need favorable loan rates and access to capital, a strong relationship with a banking institution may assist them in this. If we have the hypothetical Acme Bank as the focal agency, then all other firms that form an interlock with Acme Bank are a part of this interorganizational set. Essentially an interorganizational set can be an expanded network of all actors or organizations with whom an entity has a relationship.

An interorganizational network is a more expansive corporate network that is constructed "by finding the ties between all organizations in a population" (Aldrich, 1979, p. 281). Interorganizational networks have been studied by Domhoff $(1967,2002)$ whose work expands the focus to look at secondary interlocks and beyond and the networks that they form. Secondary interlocks can be described by the following example: Board Member 1 forms an interlock between Company A and Company B. Sitting on the board of Company B is Board Member 2 who also sits on the board of Company C. Thus, Board Member 2 forms an interlock between Company B and Company C. Board Member 1 does not sit on the board of Company $C$, but by sitting on the board of Company B with a board member of

\footnotetext{
${ }^{6}$ That is, after variables are controlled for in that relationship
}

Company $\mathrm{C}$, a secondary interlock is formed between Company A and Company C.

R. Jack Richardson (1987) posits that "many analysts have argued that some forms of intercorporate relationship can significantly impede the effective operation of the market, increase corporate concentration, and give rise to concentrations of economic power" (p. 367). ${ }^{7}$ While some argue that the presence of interlocks is simply an exercise in the corporate cohesive "good-old boys" networks among a community that are heavily networked through their personal relationships (Strauss, 2002), Taylor explains (2000) that "members of this "network" attempt to shield themselves from unqualified individuals by under- taking projects only infrequently with unproven nonmember... [and] because a successful recruitment creates a public good for network members, far too little recruiting is performed in equilibrium" (p. 886).

There are two sides to the discussion of corporate cohesion. Pluralists (Dahl, 1961; Polsby, 1980) and structural Marxists (Offe, 1974; Poulantzas, 1975) "have argued that individual corporations are too concerned with their own particular interests to constitute an effective unified force. Elite theorists (Mills, 1956) and instrumental Marxists (Miliband, 1969) have argued that the business community possesses unifying mechanisms that enable it to present itself as a cohesive entity" (Domhoff, 1987, p. 204). ${ }^{8}$

The purpose of this study is not to assess whether this need to maintain environmental certainty is present, that has already been clearly established, but why certain industries be non-intuitively interlocked with other industries and what specific motives these interlocks may reveal.

Since we can assume that interlocks occur purposely, and are not coincidental, then some interlocks can lead us to understand how some industries affect others. Thus, the argument is if petroleum and defense have a standardized interlock quotient greater than the mean quotient across all industries, there must be a tactical reason for this interlock. Exploring Haija's (2009) study on interlocks in the petroleum-defense industry, there are strong interlocks between industries that would seem coincidental, however, in the case of petroleum and defense, both industries rely heavily on U.S. policy and governance for their success and prosperity, thus, a stronger than normal interlock may indicate something more than coincidence.

What is oft overlooked is that interlocks come at a price, namely the loss of independence, and therefore we must assume that they are made purposively. As Hall and Tolbert (2005) explain: At the societal level, there has been a long-

\footnotetext{
${ }^{7}$ Richardson cites the work of Galbraith, 1971; Pfeffer and Salancik, 1978; Mintz and Schwartz, 1985, following this passage.

${ }^{8}$ This quotation is derived from G. William Domhoff's (2002) book, "Who Rules America"
} 
standing concern with the actual and potential power of the "military-industrial complex." This refers to interorganizational patterns linking the military with industry into a powerful set of organizations through interlocking boards of directors have become the focus of intense scrutiny by political and organizational sociologists (p. 189).

This study is more than a continuation of previous work on the military-industrial complex, but rather an amendment to the concept itself. I argue that an additional industry, the petroleum industry, has been added to the network of defense organizations to form a new complex. This new "complex" will be referred to as the "defensepetroleum-policy" complex. I propose that the militaryindustrial complex has coalesced with government through the use of board members with strong government credentials to potentially shape foreign policy and intervention in a way that benefits this new "complex."

Throughout the 2000s research began to emerge on the impacts of deindustrialization of the manufacturing sector in the U.S. that occurred between the 1970s and 1990s (Berger, 2007; Brady and Wallace, 2001; Johnson 2002). This rapid period of deindustrialization devastated industrial towns affected by the widespread factory closures and in the process, and moved the U.S. from a manufacturing-based economy to a mostly service and information-based economy [Bell, 1976 (1973)].

With the industrial sector in the U.S. severely languishing, I propose that the "military-industrial" complex, as elucidated by Dwight Eisenhower in his farewell address, is no longer applicable to the reality of what exists in the U.S. in this first decade of the $21 \mathrm{st}$ Century. Rather, this concept should be replaced by a modified one, the "defense-petroleum-policy" complex. During the Eisenhower period the defense manufacturing and service sector was almost exclusively controlled by the state. With the emergence of the private defense sector, the state has become reliant upon these defense contractors to provide weaponry, services, and even troops, which were once only provided by the state. Thus, the "military" component of the military-industrial complex has been replaced by the "defense" component, denoting the shift to from the military component to a private defense sector.

It is argued that the petroleum entity within this new proposed complex of "defense-petroleum-policy" takes ultimate primacy, overrunning government and policy and becoming "king" in the U.S. economy and the primary focus of U.S. foreign policy (Pfeifer, 2007). The potential for this has been long coming, as Peter R. Odell (1979) writes, "[the] organization of a large part of the international oil industry has, for a long time, been part and parcel of the U.S.A.'s world-wide interests in which the investments of U.S. private oil companies in virtually every country of the non-communist world are linked to and supported by official U.S. government policy" (p. 25).

More recent arguments in support of the notion that the
U.S. government protects the interests of the U.S. petroleum industry is the hands-off approach Congress took toward oil speculators when it was becoming evident that they were inflating crude petroleum prices on the open market, while supermajors were posting unprecedented consecutive quarterly profit earnings and the U.S. economy entered into an official recession (Reuters, 2008). The success of the petroleum industry has been in part through the leveraging of board members with previous legislative or lawmaking positions, as these policymakers have been able to distort U.S. public perceptions on the intentions and necessities of U.S. military inventions to maintain the appearance of "defending freedom" and "the spread of democracy." I suggest, and the evidence will corroborate that recent U.S. military actions have more to do with bolstering U.S. military power and the acquisition the precious natural resource of petroleum than they do with nation-building and the spread of U.S. defined democracy.

\section{Resource-Dependence Theory}

Interlocks are strategically important because they provide access to resources and can influence decisions corporations make that can help to reduce environmental uncertainties for organizations (Burt, Christman, and Kilburn, 1980; Burt, 1980). With the environmental uncertainties making it harder for corporations to compete in a rapidly changing globalized economy, most organizations will not sit idle while being susceptible to the uncertainties of this changing environment; instead, they will opt to "attempt to manipulate the environment to their own advantage" (Hall and Tolbert, 2005, p. 212). This argument is rooted in the premise that organizations cannot solely provide all of the resources or processes necessary for their prosperity, thus they must look for external agents to fill the voids left in areas that the organization alone cannot fill. Aldrich and Pfeffer (1976) state that "[organizations] manage their environments as well as their organizations, and the former activity may be as important, or even more important, than the latter" (p. 83). An organization has to adapt its internal approach to external factors, because external environmental factors will not adapt to the organization.

The purpose of this study is not to attack the practice of interlocking directorates. Under capitalism, one would expect interlocking directorates to exist because just as human beings need social networks to thrive, so do corporations. According to Richard M. Emerson's (1962) theory of power-dependence, relations that exist between organizations and actors generally "entail ties of mutual dependence between the parties." This logic stems from the resource-dependency theory (Aldrich and Pfeffer, 1976; Pfeffer and Salancik, 1978) which argues that because corporations are susceptible to external factors outside of their control, creating relationships that could reduce the external environmental uncertainty to some degree is 
strategically necessary. As the resource-dependence theory goes, actors or organizations will form relationships based on a mutual dependence for resources or services that individually they are unable to procure or fulfill, respectively. However, a competing notion against the theory that interlocking directorates are utilized for managing competitive uncertainty is the elite class theory of C. Wright Mills (1956). This theory holds that board members use interlocks to advance their class interests. This is strongly aligned with the class conflict elucidated by Marx and Engels in The Communist Manifesto (1998 [1848]).

The resource-dependence theory also states that organizations will manipulate their environment to suit their interests if the opportunity-structure is present to do so. This manipulation does not always occur in a network either; occasionally organizations will manipulate their environment to their advantage unilaterally. This approach stems from environmental determinism (Perrow, 1986), which posits that factors extraneous to an organization can determine the fate of an organization. A key example of this extra-organizational influence within the petroleum industry occurred in the late 1990s and early 2000s. During the late 1990s market petroleum prices were experiencing severe deflation and with an abundance of oil firms, oil executives felt that the economies of scale within the industry were suffering (PBS, 1998). The first to respond to these environmental concerns was British Petroleum (B.P.) when it purchased U.S.-based Amoco in 1998, and gained a wider stake in the U.S. market (AP, 1998). In response to this, in 1999 both Total S.A. and Exxon initiated mergers. Total S.A. acquired PetroFina, and Exxon acquired Mobil (TOTAL, 1999). The Exxon and Mobil merger formed ExxonMobil, which is currently the largest integratedenergy firm in the world (Brice, 2008). The merger of these aforementioned companies would lead Chevron to respond to the changing petroleum environment by acquiring Texaco to form the ChevronTexaco Corporation in 2001 . $^{9}$ Finally, in 2002 Conoco Inc. and Phillips Petroleum Company merged to form ConocoPhillips, the sixth and final company of what make up the supermajors. ${ }^{10}$ The supermajors refer the worlds six-largest, privately held oil companies. The mergers that occurred within this four-year period to form six supermajors occurred because of a few salient external environmental factors:

1. Deflating petroleum prices

2. Abundance of competition pushing prices down

\footnotetext{
9 In 2005 the ChevronTexaco moniker was dropped, in favor of, "Chevron Corporation" as the official name of the company.

10

The supermajors was a term coined following the mergers of what were known as domestic and international "majors," which was a previous term used in the 1960s thru the 1990s. See Sampson, A. (1975). The Seven Sisters: The Great Oil Companies and the World They Shaped. New York:
} Bantam Books.
3. The mergers that followed the acquisition of Amoco by $\mathrm{BP}$ were impacted by the strength $\mathrm{BP}$ gained in the global oil market

None of these factors were internal to the organizations that they impacted, and thus, the reduction of uncertainty came in a form far more drastic than interlocks; it actually resulted in mergers and acquisitions which would allow these now six supermajors to have greater control over price volatility and oil output into the market.

More importantly, this example demonstrates how organizations must sometimes take extreme measures when their extraneous environment becomes too volatile or their competition begins gaining too much control over the market. In this example of the evolution of the six supermajors, environmental uncertainties and threats became to great to simply apply a few interlocks to gain a better control over the market share, especially when B.P. set an initial precedent with their acquisition of Amoco. As C. Wright Mills (1956) wrote:[s] uch consolidation of the corporate world is underlined by the fact that within it there is an elaborate network of interlocking directorships. "Interlocking Directorate" is no mere phrase: it points to a solid feature of the facts of business life, and to a sociological anchor of the community of interest, the unification of outlook and policy, that prevails among the propertied class. Any detailed analysis of any major piece of business comes upon this fact, especially when business involves politics. As a minimum inference, it must be said that such arrangements permit an interchange of views in a convenient and more or less formal way among those who share the interests of the corporate rich. In fact, if there were not such overlapping directorships, we should suspect the existence of less formal, although quite adequate, channels of contact (p. 123).

Breaking down the passage by Mills (1956), it can be inferred that most interlocking directorates do not occur by mere chance, but rather have a strategic motive for their purpose (Heracleous and Murray, 2005). Further, Mills identifies an interlock as a "unification of outlook and policy," thus the interlock between petroleum had defense shares some particular interest or set of interests in policy and outlook. Mills continues by arguing that when business involves politics, this unification is further intensified and becomes more applicable to the strategy of the interlock.

Interlocks can also occur because of a power disparity, such as a large corporation that wields more power than another, a less-power organization and are able to exploit this disparity and demand that they sit on the board of this less-powerful organization because they see it in their interest as a way to reduce their environmental uncertainty (Aldrich, 1979). While this practice does occur, if the interlock is clearly only in the interest of one party in the interlock, the relationship may be heavily resisted. As Blau (1964) suggests, while many resource-dependent relationships exist out of necessity or interdependence, some organizations opt not to be formed because of the 
drawbacks or negatives that may come with a particular linkage with another organization or actor, as some potential linkages have costs that outweigh the benefits. Generally this occurs when a relationship appears that it will be mostly one-sided, where one party is benefiting more, while another party is incurring more of the cost of this relationship. In this instance, the party that is incurring cost will generally find it in their best interest not to form the relationship.

A further drawback of interlocks is the loss of independence. Because the actor or organization has agreed to this relationship, one can assume it must be perceived as being beneficial to both parties. Thus, both parties must implicitly agree not to work against each others' interest, even if that means that they cannot fully capitalize on an opportunity presented to them if that opportunity is contradictory to the interests of their partner. Therefore, the ability to act entirely in their own interests is lost and decisions must be made with consideration to the relationships within their network. This is a formidable risk that organizations take when entering an interlock or partnership, thus, corporations must consider potential conflicts of interest before they interlock.

External environmental factors are what shape the approach and policies internally within an organization. Organizations recognize that external factors may have a greater impact on their success than their own internal workings, and resourceful executives will attempt to engage and absorb those elements or entities that can help reduce the impact of those environmental factors. One primary way this is done is through interlocks with firms or industries that have a direct impact on their organizations' access to resources or cost of operation, such as an airline forming an interlock with a petroleum firm. R. Jack Richardson (1987) conducted a study showing that when an interlock was broken between two industries, generally it was replaced by an interlock with a corporation within the same industry as the corporation with which the link was broken. This further substantiates the proposition that organizations form interlocks out of strategy with other organizations that they deem will have a direct impact on their environment.

From these examples it can be argued that a shortcoming of resource-dependency theory is its absence of the state within the discussion of environmental influences and resource dependence. The state exercises a substantial control over the organizational structure in the U.S. and one strategy organizations undertake in minimizing the impact of environmental factors is through manipulating laws, policies, and governmental regulations that can affect the prosperity of a company.

If one considers the argument of resource-dependence theory and its relative ignoring of the state as a shortcoming, resource-dependence theory could be strengthened by a broader consideration of power. In short, the most essential aspect to the survival of an organization is power, and what is it that makes an organizational structure powerful? Mann (1988) argues that the answer depends on the actor, along with time and space factors. Thus, I ask the specific question, "Which option gives capitalist organizations the most power?" To answer this, I will first consider power more generally and how it relates to organizations.

\section{Forms of Power}

To begin this section, it is necessary to explain the concept of power. According to Max Weber [1968 (1922)] power is the ability of one to impose their will over the will of others. This definition is one of the most commonly accepted characterizations of power and Richard M. Emerson developed an elaborated explanation and concept of Weber's power definition in his power-dependence theory, making explicit that power is a property of relationship, not a single actor. Emerson (1962) explains a scenario involving two actors, (A) and (B) who form a relationship, such as an interlock, and the power that each entity possesses within this relationship:A depends upon B if he aspires to goals or gratifications whose achievement is facilitated by appropriate actions on B's part. By virtue of mutual dependency, it is more or less imperative to each party that he be able to control or influence the other's conduct. At the same time, these ties of mutual dependence imply that each party is in a position, to some degree, to grant or deny, facilitate or hinder, the other's gratification. (Emerson, 1962, p. 3)

Emerson continues by explaining that "power resides implicitly in the other's dependency" and as was explained in the previous section on resource-dependence theory, Emerson explains that the costs or benefits associated with a dependency or relationship between two actors must be weighed against the costs or benefits of "alternative" relationships that may become closed as a result of this respective relationship. $\mathrm{He}$ describes dependence specifically by the equation (Dba), which Emerson (1962) explains is:The dependence of actor A upon actor B is (1) directly proportional to A's motivational investment in goals mediated by B, and (2) inversely proportional to the availability of those goals to A outside of the A-B relation (p. 3).

Furthermore, Emerson explains that the "the dependence of one party provides the basis for the power of the other, that power must be defined as a potential influence" (p. 3). Emerson defines the concept of power by the equation, (Pab), which is the power of actor $\mathbf{A}$ over actor B is the amount of resistance on the part of $B$ which can be potentially overcome by A. Emerson further asserts that dependence and power are equal, $(\mathrm{Pab}=\mathrm{Dba})$ because, "the power of $\mathrm{A}$ over $\mathrm{B}$ is equal to, and based upon, the dependence of $\mathrm{B}$ upon A. [Thus], recognizing the reciprocity of social relations, a power dependence relation can be represented as a pair of equations: $\mathrm{Pab}=\mathrm{Dba}$, [and] 
$\mathrm{Pba}=\mathrm{Dab}$ " (p. 4).

This definition may lend some explanation as to why Citigroup, the largest financial services firm in the world, has such an impressive reachability of interlocks. Banking institutions have the ability to impose power because they hold resources that are paramount to the success of any company. According to Emerson's definition of power and dependency, these banking institutions likely control the balance of power within their relationships. This is because banking institutions control the most basic commodity in capitalism: money. Money drives capitalism because every organization is susceptible to borrowing during times of expansion, hardship, or development.

Domhoff (2005) points out that "Ford Motors and Yum! Brands have interlocks with both Citigroup and J.P. Morgan Chase, which of course means there are organizational links between those two large banks." Banking institutions tend to run the gamut in regards to which type of companies they will have interlocks with and this is because every company, from America's largest automotive maker to a snack producer, has a vested interest in interlocking with a bank. We know that these interlocks are purposeful and occur to reduce environmental uncertainty and gain access to necessary resources (Hall, 2002; Haunschild and Miner, 1997). Thus, from this example, it can be determined that in most interlocks there is a tactical and calculated decision to form that particular relationship. Pairs of industries that have a strong degree of connectedness are generally those which affect one another's environmental uncertainties, and thus the strong degree of connectedness is purposeful. However, when we come across two industries such as oil and defense, and notice their significant degree of interlock despite the lack of impact on one another environmental uncertainties, it poses the question as to whether there is the same calculated and tactical approach to form a strong relationship between these two industries as there are between others? Moreover, if such a tactical approach can be found, why is this case?

At face value there is nothing that seems to be wrong or illegal with the practice of forming organizational networks, as long as interlocks do not occur within competing firms. The creation of networks in the interest of stability is something that occurs universally on the individual level. Human beings create networks with other human beings for a variety of reasons. Some networks exist for survival, some exist for trade and bartering, some exist for enjoyment. Whatever the reason for these networks, humans long found that creating partnerships or connections with other human beings is usually in their best interest and provides services and outcomes that could not be attained or achieved without these networks. Therefore, we should expect to see networks on the organizational level; largely they develop from basic human interaction and the search for fulfilling needs and interests through networks. As Ferdinand Tonnies [2002,
(1887)] explained in his conception of the gemeinschaft society as well as Emile Durkheim's [1997(1893)] notion of mechanical solidarity, when networks between individuals are strong and personal, the outcome for the individual is more positive. Applying these concepts at an organizational level, when relationships between organizations are strong and have mutual benefit, such as those that exist in an interlock or a network, the benefit to the organization should then also yield a more positive outcome.

Domhoff (2005) expands his argument on power distribution by directing his argument toward Michael Mann's (1986) theory of power. Domhoff (2005) explains organizational interlocks in the context of Mann's fournetwork set: ideological, economic, military, and political power sets, which Mann describes as "overlapping and intersecting sociospatial networks of power" (Mann, 1986, p. 1). ${ }^{11}$ The basis of this power structure, according to Domhoff (2005) and Mann (1986) is that each of these separate entities "presupposes" the other, meaning that while they are separate in their function, and some may be more important than others depending on several factors such as time and place, they are unified because they support each other and perpetuate each other's existence. The relevance to this study can be explained in the following passage by Domhoff (2005):One kind of organizational power can be turned into any one of the others. Economic power can be turned into political power. Religious power can generate military power. Military power can conquer political power. And so on. In that sense, power is like the idea of "energy" in the natural sciences: it cannot be reduced to one primary form. Thus, there can be no "ultimate primacy" in the "mode of production" or "the normative system" or "the state," as in rival theories.

This relates to the work of C. Wright Mills (1956) and Weber (1968) who view power as ubiquitous to social relations, with the amount of power held by a person or organization capable of being increased, reduced, or transferred, but never destroyed. Analogous to this is the theoretical explanation of energy within physics which states that energy cannot be created nor destroyed, only transferred or transformed. Thus, power always exists and certain forms of power can be conquered and by conquering a specific power-set, if the notion is accepted that power is zero-sum, then that power that is lost by one power-set will invariably get absorbed by another powerset.

An example of power being absorbed by another powerset is New York City (NYC) Mayor and billionaire, Michael Bloomberg, who was able to transition his significant economic power into political power when he became the Mayor of NYC in 2001 (Left, 2001). Bloomberg was initially known to most for his billion-

\footnotetext{
${ }^{11}$ Originally cited in Domhoff, 2005.
} 
dollar NYC-headquartered global corporation, Bloomberg L.P., a financial software services firm. Benefiting from his well-known name and fortune, Bloomberg spent about $\$ 50$ million of his own money, narrowly winning the NYC mayoral election in 2001 (Left, 2001), despite having no previous political experience.

From Mills (1956) and Weber's (1968) elucidations of power and its diffusions it could be assumed that if Bloomberg did not have the economic power, his candidacy for New York mayor likely would have been a futile attempt at entering public office. Bloomberg was able to use his power in one arena, economic, to procure power in another arena, political. Importantly, however, is that Bloomberg did not necessarily relinquish any of his economic power to gain political power. Rather, he used his economic power and reputation to gain more power, this in the political realm, and thus, take power from another entity or actor.

Just as these organizational power networks can work to bolster one another, they can also the demise of one another The 2008 economic meltdown in the U.S. which financial institutions collapsed resulted in some political actors, largely Republicans, to lose support among their constituents because the general populace blamed the party in power for causing this economic calamity (CNN, 2008). ${ }^{12}$ With Republican Party losing control of the White House and both the Senate and the Congress in 2008 and 2006 , respectively, this may potentially lead to a decreased primacy of the military organization while Democrats hold a majority. According to Benjamin O. Fordham (2007), since the mid-1960s Republican presidential administrations have tended to favor increased military spending and use of the military, and have afforded it more power than Democratic presidential administrations in this modern era. Thus, some organizational power breakdowns can affect other organizational powers in an adverse way.

While defense contractors may favor Republican administrations because of their munificent military spending, looking at campaign contributions in the 2004 and 2006 election cycles, it appears that the petroleum industry also heavily favors Republican candidates as well. According to the Center for Responsive Politics, campaign donations, from both individuals and political action committees, for political candidates from the petroleum industry favored Republicans substantially, with 80 percent of the \$26 million donated in 2004, and 82 percent of the \$20.2 million donated in 2006 going to the Republican candidates (Center for Responsive Politics, 2009). Campaign donations from the defense industry were not quite so lopsided, but significantly favored Republican candidates as well. In $2004,60 \%$ of the $\$ 8.1$ million in campaign contributions from the defense industry went to

\footnotetext{
${ }^{12}$ This is according to a CNN/Opinion Research Corp Poll which suggested that Americans blame Republicans by a 2-to-1 margin for the 2008 financial crisis.
}

Republican candidates, while $58 \%$ of the $\$ 7$ million went to Republicans in 2006 (Center for Responsive Politics, 2009). Research has shown that there is a direct correlation between big donor campaign contributions and voting and legislative behaviors in favor of the donor's interests. (Jones and Keiser, 1987; Neustadl, 1990; Gordon, 2005). The disparity in campaign contributions from the petroleum and defense industries for Republicans over the Democrats indicates that these industries may view the Republicans a stronger ally who works in their interests more readily than Democrats. This is an example of the petroleum and defense industries exploiting a political power network to gain greater control over environmental uncertainties, such as those from the political power set.

Mann (1986) emphasizes how separate power networks are able to play off one another or come together in tertiary relationships for particular time and space necessities. Three of the four forms of power discussed by Mann (1986), economic, military, and political, compel an individual to participate, regardless of whether it is against his or her own interests. As Marx [1959, (1932)] elucidated in his explanation of the alienation of the worker within capitalism, these forms of power require the worker to participate or become among the lumpenproletariat. By losing control over their work, the worker inevitably begins to lose control over their life and that control is taken over by those that control economic, military, and political power, and thus, there is an obligation to participate and not resist the power structure as a matter of survival. What is further important to note is that no power takes primacy over the other, but which form of power, whether ideological, economic, military or political are more powerful at a given moment varies within time and space considerations.

In his tripartite model of power, Hawdon (2005) explains that holding economic, political, or military power over a person or group is fleeting because this imposition of power is not predicated on an actual adoption of ideals, but instead is participated in because it is obligatory. Conversely, ideological power, such as that based on religious beliefs, necessitates a type of "divine" authority for which morality and guilt are ever-present. These features can dictate action and supreme loyalty. While ideological power is not necessarily the most powerful of the four types of power, it is the most enduring. It is important to mention that just because ideological power is seemingly voluntary, it is actually coercive. Just as Weber [1968 (1992)] explicated, all exercises in power are coercive because it involves the imposition of the will from one actor or institution over the will of another actor or organization.

As Domhoff (2005) explains that "since the four networks are not encompassed within a larger social framework or any one physical territory, there is no need for concepts such as a "bounded society" or a "social system." Since there is no "totality," there can be no 
"subsystems," "levels," or "dimensions." Instead, social organization must be understood in terms of the four overlapping networks of power that run off in different directions and have varying extensions in physical space. Essentially power cannot be explained in sub-systematic terms because there are no levels of power. Its form can be constantly changing and any one of the four-modes of power can overtake power from the others and be the dominate mode of power in that particular time and space (Domhoff, 2005). It is therefore important to be aware that the four-network theory of power transcends organizational studies and extends into competing with Durkheim's [1997(1893)] "agency v. structure" debate. ${ }^{13}$ This, Domhoff suggests, "[is] because the four-networks have different and constantly changing boundaries that vary with the invention of new technologies and the emergence of new organizational forms..." (Domhoff, 2005).

In sum, while the four forms of power overlap, none take primacy, although one may at a given moment. And while interlocks can often come at a cost, such as the loss of independence, or the benefits becoming largely favorable to only one actor, they ultimately give the organization more power by connecting economic, military, ideological, and political power. Thus, assuming interlocks are beneficial and entered into with intent and purpose; because if they are not, then the interlock does not perform its necessary function.

Thus, to understand why corporations in non-obviously linked industries and the government would create interlocks, it must be understood how all parties involved benefit. One means of gaining this understanding is to consider the power relations that benefit corporate actors and political actors. Hawdon (1996) uses this technique to explain why intergovernmental organizations (IGOs) proliferated in the $20^{\text {th }}$ century. This strategy should be fruitful in this study because IGOs and interlocks are parallel in two ways: (1) both have ties and access to government, but work independently of it; (2) both involve the behavior of organizations; (3) both are strategies that organizations pursue to reduce environmental uncertainty; and (4) both simultaneously increase the power of those involved while also limiting it. Therefore, considering the power relations involved in interlocks should be a useful analytic strategy. We now turn to a consideration of the actors involved in a defense-petroleum-policy interlock and what type of power relations each prefer

\section{Capitalism and the State}

Prima facie, the state and the capitalist class appear to be diametric opposites. Contrary to Marx [1999 (1887)] and Miliband (1969), the state and the capitalist class do not necessarily work together. Mann (1986) suggests within his source of power debate that the state is itself an

\footnotetext{
${ }^{13}$ This concept was discussed and referenced in Domhoff, 2005.
}

autonomous entity, while Poulantzas (1975) argued that although the capitalist class facilitates the perpetuation and success of the state through support of its legitimacy, this is because it is in the interests of the capitalist class to have a functional state. In accordance with Weber's explanation of the three forms of authority, traditional, charismatic, and legal-rational legitimacy, only legal-rational legitimacy applies to the state (Poggi, 1978). Jessop (2002) follows these arguments with his proposition that capitalism itself is a social relation as part of a larger system within the state.

Hawdon (1996) makes an important contribution to this debate between capitalists and the state when he argues that capitalists may view the state as an adversary because the state attempts to regulate the corporate structure through legalities and the state imposes taxes on capitalists. When capitalists are major holders of a necessary resource, they may form an agreement with other. If not regulated by the state, elements within the capitalists may attempt to executive a monopoly over this resource in an effort to increases the value of this resource. The state makes mergers and acquisitions lengthy processes for the capitalist class, and if the resources of fractions of the capitalist class become too abundant or monopolized, the state will force the break up of the corporation and require that these fragments of the former company be sold, as it did when the United States Supreme Court broke up Standard Oil in 1911 (Yergin, 1993).

The state regulates the competition strategies of the capitalist class as well. If the capitalist class executes predatory pricing strategies in an effort to eliminate competition, then the state will intervene and penalize those in the capitalist class guilty of this activity. So, strategies that may prosper the capitalist class are regulated by the state.

Furthermore, the state limits interaction that the capitalist class can have or measures that they can take in order to preserve or prosper their wealth. As an example, the capitalist class cannot wage war on a nation, doing so would be a threat to their legitimacy, even if waging war on a nation and acquiring its resources is necessary for their continued prosperity. Thus, the capitalist class needs the state to wage its battles, because as Weber (1919) elucidated, the state holds the monopoly on the legitimate use of physical force.

Most importantly, while the capitalist class benefits from decentralized power relations, the state benefits from centralized power relations (Hawdon, 1996). The capitalist class benefits from decentralized power relations because a decentralized system extends markets by weakening nationalistic trade barriers. The state, however, benefits from centralized systems of power because its power is intensive and limited to a specific territory (see Hawdon 1996; also see Mann 1986). Thus, the state and the capitalist class are in a constant struggle because they are organizational rivals.

Yet, while the state and the capitalist class are 
organizational rivals, they are rivals that need each other. From the state's perspective, the reason they need capitalist class is that the state must legitimate itself, but the state does not produce anything directly (Mann 1986; Hawdon 1996). The state must acquire economic resources from others, and this is accomplished through either taxing capitalist production or through military conquest. Conquest is possible source of revenue for the state. The state gains legitimacy in part from its monopoly over the use of force and control of the military, but if the state relied solely on itself to advance its military and battle technologies and capabilities, the state runs the risk of suffering delegitimation and the loss of military power. Kennedy (1987) argues that Europe ascended to hegemony because no state or territory had a monopoly over military power and thus, each state and territory continued to make advances in military technology. This Kennedy believed is because when the state is not the only producer of weaponry, the opportunity for technological advancements is given to the private sector, where improvements can progress move rapidly. Since in the other power centers of the $15^{\text {th }}$ century world, strong states monopolized military technology and this monopoly limited advances in weaponry, Europeans quickly gained an advantage over peoples from other lands. It was this advantage, at least according to Kennedy (1987) that led to the European powers colonizing much of the world. The same statecapitalism relationship holds true in the U.S. today, as technology improves with more competition in the defense industry resulting in benefits to the state and further legitimation for the state because of its military strength and advances. As Kennedy (1987) explains: [the] explosion in new technological and scientific developments since the late nineteenth century inevitably drove defense manufacturers into a relationship with government which deviated from the "free market" norms, [and] the present pace of this increase is an alarming one...[the] trend toward ever fewer weapons at an even higher cost. While much of this is of course due to the growing and inescapable sophistication of weapons... it is also caused by the continuing array of arms races on land, on and under the ocean, in the air, and in space (p. 443).

As Rothe writes, "[t]he intersection of state and corporate interests during times of war is a fundamental part of the war-making process. Every Capitalist country must rely on private-sector production to produce the weapons of war" (p. 215). In addition, the state, if it purports to be a democracy, cannot wage war without the support of some of its populace or it threatens its legitimacy as the will of the people. Consequently, while the conquest of others is a possible source of resources for the state, this strategy comes at a cost and places the state in a vulnerable position relative to capitalists. Thus, the state must raise revenues using their other strategy: taxes. This strategy, however, also puts the state in a dependent position with respect to capitalists. As Jessop (2002) explains, "[t]he ecological dominance of capitalism over modern states is mediated in part through state managers' calculations about the likely impact of their decisions on alterations in the money markets and fisco-financial system on which state revenues depend" (p. 25). Thus, the state must look out for the interests of the capitalist class because they are the conduit through which the state generates revenue. Moreover, it is through the spending of that revenue to address income inequalities and intercept economic dysfunction that the state maintains legitimacy (Habermas, 1973).

Hawdon (1996) references Mann (1988), when he outlines the functions of the state: "(1) the maintenance of internal order; (2) military defense and aggression; (3) the maintenance of communication infrastructures (roads, rivers, message systems, coinage, weights and measures, marketing arrangements, and; (4) economic redistribution. Thus, the state cannot carry out any of these functions without the tax revenues and resources brought to it from the capitalist class.

Without tax revenues from the capitalist class, the state will suffer an economic crisis, which in turn results in a legitimation crisis for the state. As Habermas (1975) explains, "because the economic crisis has been intercepted and transformed into a systematic overloading of the public budget if governmental, it has to put off the mantle of a natural fate of society. If governmental management fails, it lags behind programmatic demands that it has placed on itself. The penalty for this failure is withdrawal of legitimation" (p. 69). The state must produce something of perceived value to gain some sort of legitimacy and if that is not produced, then the state must enter into another form of legitimation. The state will continually experience insecurities in regards to its legitimacy among its populace and there is a constant need to reinforce its perceived legitimacy. In Poggi's (1978) words, “[a]s a system of rule, the state confronts the problem of legitimacy. That is, it wants its citizens to comply with its authority not from the inertia of unreasoning routine or the utilitarian calculation of personal advantage, but from the conviction that compliance is right" (p. 101). This argument, that compliance out of conviction is the state's ultimate goal, is consistent with the proposition of ideological power being the most enduring, and therefore the most highly sought (Hawdon, 2005). It also demonstrates that the state needs their capitalist rivals.

The capitalist class, however, also needs the state, for the state provides specific services to the capitalist class that it cannot provide for itself. Specifically, the state secures trade routes and provides piracy protections for the capitalist class (Kennedy, 1987). The state acts to secure credit and loans for the capitalist class and enforces prosecution when repayments are not made. The state spends tax revenues that end up in the hands of consumers which in turn result in consumer purchases that benefit the capitalist class (Hawdon, 1996). The state, particularly a 
powerful state, with the ability to impose its will over the will of other states, can deregulate the economies of foreign countries which allow the capitalist class access to an economy that was once restricted. This economic strategy, known as neoliberalism, was a common theme in the G.W. Bush administration as a condition for developing nations to secure loans from the U.S. dominated World Bank, under what are known as structural adjustment programs (Juhasz, 2006). Structural adjustment programs are a passive and less obtrusive measure that the state may use at gaining access to resources for the capitalist class. Finally, and most importantly, the state provides the legitimating ideology that keeps the masses of exploited people from overthrowing their exploiters, the capitalist class.

During the G.W. Bush administration it can be argued that the state championed the legitimating ideology of patriotism, which can be seen as an attempt to gain one of the power types described in Mann's (1986) power-set, specifically the ideological power type. The use of patriotism by the state is a form of "cultural leadership" as described by Gramsci [1996, (1957)] in which the state utilizes an ideological notion to coerce its populace to act in the interests of the state and the capitalist class. Through this hegemonic ideology, Gramsci [1996, 1957)] explains, the state is afforded legitimacy and compliance from its populace, and, in turn, the capitalist system is protected and willingly participated in by those whom it exploits.

Patriotism is important to the capitalist class in other ways as well. If a sentiment existed among U.S. citizens of being tied to the global community, individuals might begin to tie themselves with those around the world with whom they do similar work. This poses a problem for the capitalist class because the capitalist class benefits from exploiting individuals in the Global South by not paying them a living wage for their work. This is partly done to deliver products to the Western consumer at a more competitive price. The danger of the American worker identifying with those in the Global South who is do similar work to theirs, yet are not making a living wage, is that the American worker may feel he or she is contributing to that exploitation, and this concern or guilt is threatening to the capitalist class. Thus, the legitimating ideology of patriotism that is disseminated by the state serves both the interest of the state as well as the capitalist class because the individual identifies him or herself with the state, rather than as a member of the global community.

Furthermore, the state relies on the legitimating ideology of patriotism to justify war to its populace, and this is of benefit to the capitalist class if the proposed military conflict is in a region that has opportunities for the capitalist class to profiteer off U.S. military presence and dominion over the region.

Applying these aforementioned theories to the defensepetroleum-policy complex, I suggest that the defense industry prospers almost exclusively when defense contracts are given to it by the state, and in order to prosper, the petroleum industry needs either market volatility or access to known petroleum reserves. These two criteria can both be satisfied with the overthrow of leadership in oilrich nations, or increasing instability in those regions. Petroleum firms do not hold the legitimacy or capacity to declare war or covertly overthrow leaders of foreign nations rich with oil; only the state can provide these functions. In turn, the capitalist class can provide one of the legitimating characteristics of the state; employment for the American workforce, which is necessary to maintain acceptable approval ratings for the state. In the process, the capitalist class can secure the vital resource of petroleum, which is considered essential to the continued prosperity of the state $(\mathrm{CNN}, 2008){ }^{14}$ If a state is without jobs and unable to get access to the necessary resources it needs for stability, then the state that will lose legitimacy rather than corporations that provide these necessary resources (Habermas, 1975).

The state needs the petroleum industry to thrive because the resource it provides are necessary for economic growth; while the petroleum industry benefits from the system the state maintains and legitimates. And, both the state and the petroleum industry need the defense industry to advance their interests. But of course, the defense industry is dependent upon the state to contract for their products. Consequently, all three of these actors are in a highly interdependent relationship. Therefore, the state needs the capitalist class, and the capitalist class needs the state.

So if state and the capitalist class are rivals that need one another, how can we theoretically bridge this divide? The divide between these two conflicting organizational entities is bridged through the interlocking governmental director. The interlocking governmental director is a board member who served as a former policymaker, bureaucrat, or military leader and is receiving a sizable sum of money to look after the interests of the corporation for which they are board directors, and their primary responsibility is to advance the financial interests of that company. Therefore, the strategy of corporations to seat a former government official on their board is done for several reasons: to bridge the gap between the organization and that state, to assist in reducing some of the government imposed environmental conditions that prove problematic for the capitalist class, and to influence the state into actions that are beneficial to the capitalist class. According to Burris (2005), "the politically cohesive effects of directorship ties remain robust even as one moves several links down the chain of indirect ties that connect top corporate officers to one another" (p. 249). So this strategy of bridging the two competing organizational entities, the state and the capitalist class, appears to be a common practice.

\footnotetext{
${ }^{14}$ In the summer of 2008 , former Vice-President Al Gore warned that the energy crisis is a threat to the survival of the U.S.
} 
In closing, just as different types of power vary in their degree of power within time and space, so too does the power struggle between the state and the capitalist class. Hawdon (1996) explains, "[g]iven the opposing nature of the optimal forms of the state and capitalism and that those systems are highly interdependent, it is unlikely that both systems can achieve their optimal form simultaneously. [a] given stage of the process will find the state being "optimized," however, before the next stage occurs, capitalism will be "optimized," and therefore the state's power will be lessened" (p. 28-29). Given the actions of the G.W. Bush administration to exercise military or covert actions in regions rich in petroleum, this could suggest that a balance of power exists with the defense and petroleum industry capitalists over the state.

\section{Bibliography}

[1] Aldrich, H. E. (1979). Organizations and Environments. Englewood Cliffs, N.J.: Prentice Hall.

[2] Aldrich, H. E., and Pfeffer, J. (1976). Environments of Organizations. Annual Review of Sociology, 2, 79-105.

[3] Associated Press. (1998, December 1). Exxon, Mobil Confirm Merger. Associated Press.

[4] BBC News. (2007, Oct 8). Iraq urges Blackwater prosecution. Retrieved January 20, 2009, from http://news.bbc.co.uk/2/hi/middle_east/7033048.stm

[5] Bearden, J., and Mintz, B. (1985). Regionality and Integration in the United States Interlock Network. In F. Stokman, R. Ziegler and J. Scott (Eds.), Networks of Corporate Power (pp. 234-249). New York: Blackwell.

[6] Bell, D. (1976 (1973)). The Coming of the Post-Industrial Society. New York: Basic Books.

[7] Berger, J. (2007). "There is tragedy on both sides of the layoffs": Privatization and the Urban Crisis in Baltimore. International Labor and Working-Class History, 71(Spring), $29-49$.

[8] Blau, P. M. (1964). Exchange and Power in Social Life. New York: Wiley.

[9] Brady, D., and Wallace, M. (2001). Deindustrialization and Poverty: Manufacturing Decline and AFDC Recipiency in Lake County, Indiana 1964-93. Sociological Forum, 16(2), 321-358.

[10] Brice, A. (2008, September 22). Ups and downs. ICIS Chemical Business.

[11] Burris, V. (2005). Interlocking Directorates and Political Cohesion among Corporate Elites. American Journal of Sociology, 111(1), 249-283.

[12] Burt, R. S. (1980). Cooptive Corporate Action Networks: A Reconsideration of Interlocking Directorates Involving American Manufacturing. Administrative Science Quarterly(25), 557-582.

[13] Burt, R. S., Christman, K. P., and Harold C. Kilburn, J.
(1980). Testing a Structural Theory of Corporate Cooptation: Interorganizational Directorate Ties as a Strategy for Avoiding Market Constraints on Projects. American Sociological Review(45), 821-841.

[14] Caplow, T. (1964). Principles of Organization. New York: Harcourt Brace Jovanovich.

[15] Carter, J. (1980). State of the Union Address.

[16] CNN. (2008, July 18). Energy crisis threatens U.S. survival, Gore says. Retrieved September 28, 2008, from http://www.cnn.com/2008/POLITICS/07/17/gore.energy/ind ex.html

[17] CNN. (2009, January 29). Iraq denies Blackwater an operating license. Retrieved January 29, 2009, from http://www.cnn.com/2009/WORLD/meast/01/29/iraq.black water/index.html

[18] Dahl, R. A. (1961). Who governs? Democracy and Power in an American city. New Haven: Yale University Press.

[19] Dao, J. (2004, April 3). Paramilitary services take off in U.S. International Herald Tribune.

[20] Domhoff, G. W. (1967). Who Rules America? (1st ed.). Upper Saddle River, NJ: Prentice Hall.

[21] Domhoff, G. W. (1987). In G. W. Domhoff and T. R. Dye (Eds.), Power Elites and Organizations. Thousand Oaks, CA: Sage Publications.

[22] Domhoff, G. W. (2002). Who Rules America? Power, Politics, and Social Change (4th ed.). New York: McGrawHill.

[23] Domhoff, G. W. (2005). Interlocking Directorates in the Corporate Community. Retrieved September 10, 2007, from http://sociology.ucsc.edu/whorulesamerica/power/corporate community.html

[24] Durkheim, E. (1997 (1893)). The Division of Labour in Society. New York: The Free Press.

[25] Emerson, R. M. (1962). Power-Dependence Relations. American Sociological Review, 27(1), 31-41.

[26] Fenno, R. F. (1978). Home Style: House Members in their Districts. Boston: Little, Brown.

[27] Goodman, A., and Scahill, J. (1998, November 16). Drilling and Killing. The Nation.

[28] Gramsci, A. (1996). Prison Notebooks (Vol. I-II). New York: Columbia University Press.

[29] Habermas, J. (1975). Legitimation Crisis (T. McCarthy, Trans.). Boston: Beacon Press.

[30] Hawdon, James E. (1996). Emerging Organizational Forms: The Proliferation of Intergovernmental Organizations in the Modern World System. Greenwood Publishing Group.

[31] Haija, R. M., Wimberley, D. W., and King, R. C. (2008). Corporate Allies Divided: The Dearth of Corporate Interlocks between U.S. and European Firms, Southern Sociological Society Annual Meeting. Richmond, VA.

[32] Hall, R. H. (2002). Organizations: Structures, Processes, and Outcomes (8th ed.). Upper Saddle River, NJ: Pearson- 
Prentice Hall.

[33] Hall, R. H., and Tolbert, P. S. (2005). Organizations: Structures, Processes, and Outcomes (9th ed.). Upper Saddle River, NJ: Pearson-Prentice Hall.

[34] Harris, J. (2005). The Military-Industrial Complex in Transnational Class Theory. In R. P. Appelbaum and W. I. Robinson (Eds.), Critical globalization studies, edited by R. P. Appelbaum and W. I. Robinson (pp. 141-151). New York: Routledge.

[35] Haunschild, P. R., and Miner, A. S. (1997). Modes of Interorganizational Imitation: The Effects of Outcome Salience and Uncertainty. Administrative Science Quarterly $42(3), 472-500$

[36] Heracleous, L., and Murray, J. (2001). Networks, Interlocking Directors and Strategy: Toward a Theoretical Framework. Asia Pacific Journal of Management, 18(2), 137-160.

[37] Jessop, B. (2002). The Future of the Capitalist state. Cambridge: Polity Press.

[38] Johnson, C. (2006). Nemisis: The Last Days of the American Republican. New York: Metropolitan Books.

[39] Johnson, C. H. (2002). Introduction: De-Industrialization and Globalization. Introduction: De-Industrialization and Globalization, 47(Dec), 3-33.

[40] Juhasz, A. (2006). The Bush Agenda: Invading the World, One Economy at a Time. New York: HarperCollins.

[41] Kennedy, P. (1987). The rise and fall of the great powers: Economic change and military conflict from 1500 to 2000 . New York: Random House.

[42] Mann, M. (1986). The sources of social power: A history of power from the beginning to A.D. 1760 (Vol. 1). New York: Cambridge University Press.

[43] Mann, M. (1988). The Amplification of State Power, University of Virginia, Department of Sociology Colloquium Series. Charlottsville, VA.

[44] Marx, K. (1999 (1887)). Capital. Oxford: Oxford University Press.

[45] Marx, K. (2008 (1847)). The Poverty of Philosophy. New York: Cosimo Classics.

[46] Marx, K. (1932 [1959]). Economic and Philosophic Manuscripts of 1844 (A. Blunden, Trans.). Moscow: Progress Publishers.

[47] Marx, K., and Engels, F. (1998 (1848)). The Communist Manifesto. New York: Penguin Group.

[48] Merton, R. K. (1957). Social Theory and Social Structure. Glencoe, IL: Free Press.

[49] Miliband, R. (1969). The State in Capitalist Society: Quartet Books.

[50] Mills, C. W. (1956). The Power Elite. Oxford: Oxford UP.

[51] Mizruchi, M. S., and Koenig, T. (1986). Economic Sources of Corporate Political Consenses: An Examination of Interindustry Relations American Sociological Review 51,
482-491.

[52] Odell, P. R. (1979). Oil and World Power. New York: Penguin Books.

[53] Offe, C. (1974). Structural Problems of the Capitalist State. Class Rule and the Political System. On the Selectiveness of Political Institutions. German Political Studies, 1, 31 - 57.

[54] Parsons, T. (1960). Stucture and Process in Modern Society. New York: The Free Press.

[55] PBS.(1998). Slick Deal?, NewsHour with Jim Lehrer.

[56] Pelton, R. Y. (2006). Licensed to Kill: Hired Guns in the War on Terror. New York: Crown Publishers.

[57] Pennings, J. M. (1980). Interlocking Directorates: Origins and Consequences of Connections among Organizations' Board of Directors. New York: Jossey-Bass.

[58] Perkins, J. (2004). Confessions of an Economic Hit Man. San Francisco: Berrett-Koehler Publishers.

[59] Perrow, C. B. (1986). Complex Organizations: A Critical Essay (3rd ed.). New York: Random House.

[60] Pfeffer, J., and Salancik, G. R. (1978). The External Control of Organizations: A Resource Dependence Perspective. New York: Harper and Row

[61] Poggi, G. (1978). The Development of the Modern state: A Sociological Introduction. Stanford, CA: Stanford University Press.

[62] Polsby, N. W. (1980). Community Power and Political Theory (2nd ed.). New Haven: Yale University Press.

[63] Poulantzas, N. (1975). Political Power and Social Classes: Verso.

[64] Reuters. (2008, January 31). Shell's Record Profit is a Thumb in the Eye of Recession-Wracked Nation, Says Group. Thomson Reuters.

[65] Richardson, R. J. (1987). Directorship Interlocks and Corporate Profitability. Administrative Science Quarterly, 32(3), 367-386.

[66] Ross, R., and Trachte, K. (1990). Global Capitalism: The New Leviathan. Albany: SUNY Press.

[67] Rothe, D. (2006). Iraq and Halliburton. In R. J. Michalowski and R. C. Kramer (Eds.), State-Corporate Crime: Wrongdoing at the Intersection of Business and Government. New Brunswick: Rutgers University.

[68] Schoorman, F. D., Bazerman, M. H., and Atkin, R. S. (1981). Interlocking Directorates: A Strategy for Reducing Environmental Uncertainty. Academy of Management Review, 6(2), 243-251.

[69] Strauss, G. (2002, November 5th). Good old boys' network still rules corporate boards USA Today.

[70] Sullivan, K. (2007, January 23). Views on U.S. Drop Sharply in Worldwide Opinion Poll. Washington Post.

[71] Tonnies, F. (2002 (1887)). Community and Service: Dover Publications. 
[72] Wright, E. O. (1996). Class Counts: Comparative Studies in Class Analysis: Cambridge University Press.

[73] Weber, M. (1968 (1922)). Economy and Society: An Outline of Interpretive Sociology (E. Fischoff, Trans.). New York: Bedminster Press.

[74] Weber, M. (1919). Politics as a Vocation, Munich

\section{University. Munich, Germany.}

[75] Weinstein, M. A. (2004). U.S. Troop Redeployment: Rational Adjustment to an Altered Threat Environment: Power and Interest News Report.

[76] Yergin, D. (1993). The Prize: The Epic Quest for Oil, Money, and Power. In. New York: Free Press. 